\title{
Italy: Financial Sector Assessment Program-Detailed Assessment of Implementation of the IOSCO Objectives and Principles of Securities Regulation
}

This Detailed Assessment of Implementation of the IOSCO Objectives and Principles of Securities Regulation for Italy was prepared by a staff team of the International Monetary Fund as background documentation to the Financial Sector Assessment Program with the member country. It is based on the information available at the time it was completed in February 2006. The views expressed in this document are those of the staff team and do not necessarily reflect the views of the government of Italy or the Executive Board of the IMF.

The policy of publication of staff reports and other documents by the IMF allows for the deletion of market-sensitive information.

To assist the IMF in evaluating the publication policy, reader comments are invited and may be sent by e-mail to publicationpolicy@imf.org.

Copies of this report are available to the public from

International Monetary Fund $\bullet$ Publication Services

700 19th Street, N.W. • Washington, D.C. 20431

Telephone: (202) 6237430 • Telefax: (202) 6237201

E-mail: publications@imf.org • Internet: http://www.imf.org

Price: $\$ 15.00$ a copy

\section{International Monetary Fund}

Washington, D.C. 



\title{
FinANCIAL SECTOR ASSESSMENT PROGRAM
}

\author{
DETAILED ASSESSMENT OF IMPLEMENTATION OF THE IOSCO \\ OBJECTIVES AND PRINCIPLES OF SECURITIES REgUlation
}

\section{ITALY}

\section{FEBRUARY 2006}

INTERNATIONAL MONETARY FUND

MONETARY AND FINANCIAL SYSTEMS DEPARTMENT 
IOSCO Objectives and Principles of Securities Regulation ..........................................

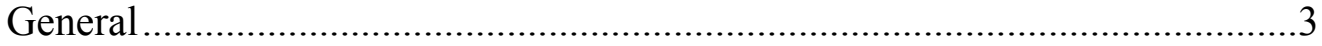

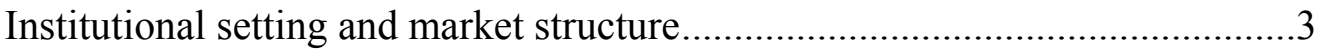

Description of regulatory structure ..................................................... 4

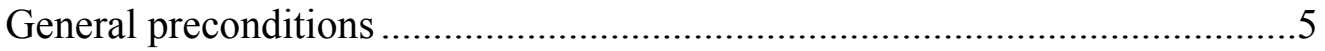

\section{Tables}

1. Detailed Assessment of Observance of the IOSCO Objectives and Principles of

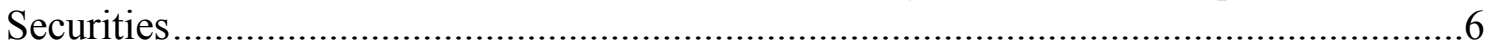

2. Summary Implementation of the IOSCO Objectives and Principles of Securities

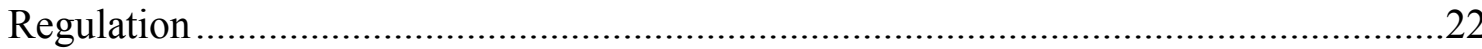

3. Recommended Plan of Actions-IOSCO Objectives and Principles of Securities

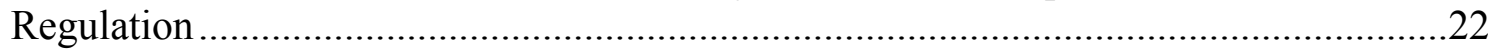




\section{IOSCO ObJectives ANd Principles of Securities Regulation}

\section{General}

1. An assessment of implementation of the IOSCO Principles was carried out as part of the first FSAP mission, during October 18 and November 3, 2004, by Jose Manuel Portero.

2. The assessment was carried out using IOSCO Assessment Methodology (the Methodology), adopted by IOSCO in October 2003. The assessment relied on a detailed selfassessment completed by Consob and Banca d'Italia, in-depth interviews with Consob, BI and the Ministry of Economy and Finance staff, interviews with market participants and industry associations, and a review of key pieces of legislation.

3. The assessment was made possible by the generosity and due diligence of Consob and Banca d'Italia staff who were at all times very open and cooperative. The assessor would like to extend his appreciation to market participants and industry associations for their time and contribution to this report.

\section{Institutional setting and market structure}

4. The Italian securities market, as other European markets, is a bank dominated industry. In 2003, there were 710 banks and 131 investment firms, mostly controlled by Italian banks and Italian financial groups, authorized to carry out investment services from the reception and transmission of orders to dealing on their own account and providing underwriting services. ${ }^{1}$ Additionally 153 asset management companies, mostly controlled by Italian banks, and 1556 CIS were registered, including open-end mutual funds, close-end private equity funds, closed-end real estate funds and hedge funds, with a total of EUR 403.722 million assets under management. ${ }^{2}$

5. In 2003, three market operators were authorized to manage regulated markets: the Borsa Italiana Spa (the Italian Stock Exchange), which is mostly owned by Italian banks, MTS $\mathrm{SpA}$, whose control has been recently transferred to Euronext and Borsa Italiana, and Tlx SpA, which is fully owned by Italian banks.

6. The Italian Stock Exchange, which had 128 members in 2003, manages 3 regulated equity markets (MTA, Mercato Expandi and MTAX which replaced the segment previously known as Nuovo Mercato), one market for funds (MTF), a derivative market (IDEM), a securitized derivatives market (SeDex) and two fixed income markets (MOT for government securities and corporate bonds and EUROMOT, for Eurobonds and Asset Backed securities). In 2003, the Italian Stock Exchange had a total market capitalization of EUR 488 million, EUR 475 million corresponding to the MTA market, with 219 Italian companies listed. A

\footnotetext{
${ }^{1}$ Consob statistics, as of December 2003.

${ }^{2}$ Banca d'Italia statistics, as of December 2003.
} 
total of EUR 12,524 million in equity were issued (9,868 from IPOs) in that market in 2003. In 2003 total turnover for the MOT market was EUR 142 billion, EUR 133 billion corresponding to government bonds. Total turnover for EUROMOT market was EUR 4 billion. ${ }^{3}$

7. MTS manages the government bonds wholesale market (MTS) and a multidealer to client internet based government bond wholesale market (Bondivision). In 2003 turnover for the MTS/cash segment market was EUR 2,136 billion and of EUR 12,464 billion for the MTS/repo segment. Turnover in the Bondvision was EUR 149 billion. ${ }^{4}$

8. Tlx manages the TLX market where corporate bonds, Italian and EU government bonds and funds and equity linked securities are traded. In 2003 total turnover was EUR 2 billion. ${ }^{5}$

9. Both the central depository (Monte Titoli) and the clearing house (Cassa di Compesazione e Garanzia SpA) are mostly owned by the Italian Stock Exchange.

\section{Description of regulatory structure}

10. The 1998 Consolidated Law of Financial Intermediation (Consolidated Law) sets out the institutional framework for the regulation and supervision of the Italian securities market. Under this Law, Consob has responsibility for market efficiency and transparency, proper conduct of business by intermediaries and investor's protection, while BI is responsible for prudential supervision and financial stability of intermediaries. It also has direct responsibility for the supervision of wholesale markets in government securities, although Consob is responsible for the regulation and supervision of market abuse in that market.

11. The main provisions governing Consob are set out in Law 216/1974 as amended in the Consolidated Law. BI's organization and competences are comprised in different legal sources: its bylaws ratified by Royal Decree 1067/1936 as amended, the Consolidated Law on Banking (Legislative Decree 385/1993 Consolidated Law on Banking) and the Consolidated Law. The Consolidated Law was recently amended by Law No. 62/2005, which implemented the Market Abuse Directive. ${ }^{6}$ While most of the changes needed to transpose European Directives into the Italian legal framework have already been introduced, some are still needed to harmonize it with the Prospectus Directive ${ }^{7}$.

\footnotetext{
${ }^{3}$ Consob's statistics, as of December 2003.

${ }^{4}$ Consob's statistics, as of December 2003.

${ }^{5}$ Consob's statistics, as of December 2003.

${ }^{6}$ Directive 2003/6/EC.

${ }^{7}$ Directive 2003/71/EC.
} 


\section{General preconditions}

12. The IOSCO Principles list a number of preconditions to effective securities regulation. These include the appropriateness of legal, tax and accounting framework within which the securities market operate, the effectiveness of procedures for the efficient resolution of problems in the securities market, and the soundness of macroeconomic policies (those aspects that could affect the operations of the securities market). These preconditions appear to be in place in Italy. 


\title{
Principle-by-Principle Assessment
}

\author{
Table 1. Detailed Assessment of Observance of the IOSCO Objectives and \\ Principles of Securities Regulation
}

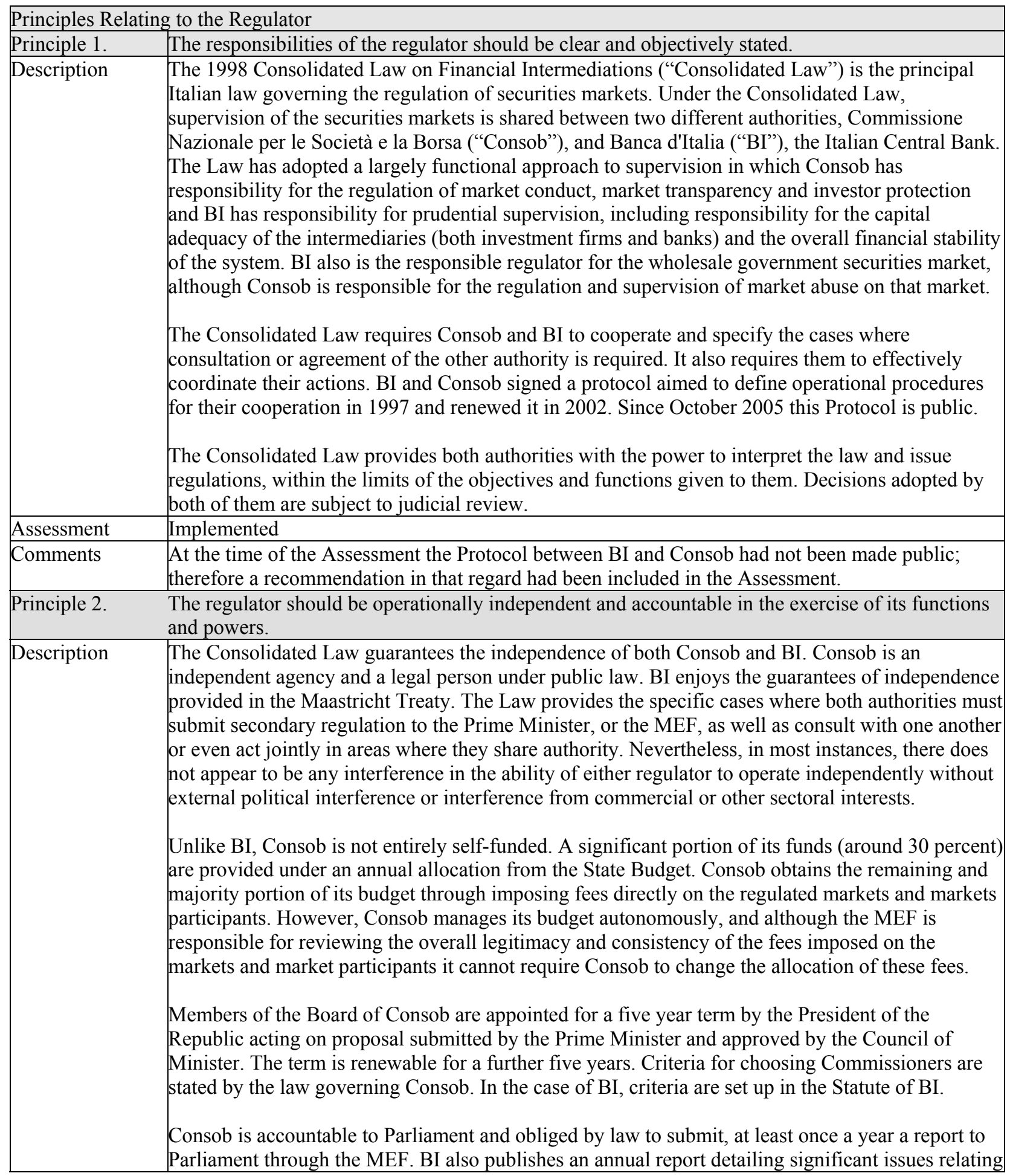




\begin{tabular}{|c|c|}
\hline & $\begin{array}{l}\text { to market supervision. Parliament is entitled to call the senior officials of each institution to } \\
\text { demand further information if it considers it necessary. } \\
\text { As regard to legal protection against suits, articles } 22-30 \text { of the Decree of the President of the } \\
\text { Republic } \# 3 / 1957 \text { which regulates civil servants are applicable to Consob staff, including members } \\
\text { of the governing body When performing their functions, Consob staff are considered public } \\
\text { officials, therefore their liability may be engaged only in cases of serious/gross negligence, fraud, } \\
\text { deceit or willful wrong. As stated in the BCP Assessment, there is no legal protection offered to } \\
\text { the BI staff and its officers against the possibility of legal action resulted from actions adopted in } \\
\text { good faith in the exercise of their supervisory functions. }\end{array}$ \\
\hline Assessment & Implemented \\
\hline Comments & $\begin{array}{l}\text { The status of legal protection of BI staff was considered for the grading in the BCP Assessment. } \\
\text { Recommendations are also included in the BCP Assessment. } \\
\text { At the time of the assessment (October 2004) Consob and BI only had the authority to propose } \\
\text { pecuniary sanctions against market participants, while the authority to impose them vested with the } \\
\text { Minister of Finance. The fact that comprehensive sanctioning responsibility did not lie with } \\
\text { Consob and/or BI detracted from their overall independence and credibility as regulators and } \\
\text { therefore strengthening of their sanctioning powers was needed for the full implementation of the } \\
\text { Principle. The recently approved Law on Market Abuse (Law No. 62/2005) rectified this weakness } \\
\text { by giving Consob and BI the authority to impose the pecuniary sanctions included in the Law. }\end{array}$ \\
\hline Principle 3. & $\begin{array}{l}\text { The regulator should have adequate powers, proper resources and the capacity to perform its } \\
\text { functions and exercise its powers. }\end{array}$ \\
\hline Description & $\begin{array}{l}\text { Consob and BI share responsibility for securities regulation under a functional approach. } \\
\text { Therefore, Consob is responsible for ensuring the fairness and transparency of the markets, the } \\
\text { correct behavior of market participants and the protection of the investors. BI focuses on matters } \\
\text { relating to risk limitation, financial stability and capital adequacy. } \\
\text { The Consolidated Law establishes in detail the powers of both regulators and the activities they } \\
\text { may perform, and identifies the persons and entities subject to their respective supervision. } \\
\text { It has to be noted that the total number of Consob staff has been fixed by the Consolidated Law (as } \\
\text { amended) at } 450 \text {. There is not a similar ceiling in the case of BI staff. However at the present time } \\
\text { the ceiling does not appear to affect Consob's ability to perform its functions. Moreover, following } \\
\text { the approval of the Law on Market Abuse Consob's staff was increased by } 150 \text { personnel. }\end{array}$ \\
\hline Assessment & Implemented \\
\hline Comments & $\begin{array}{l}\text { At the time of the assessment BI and Consob lacked the authority to impose pecuniary sanctions on } \\
\text { market participants which weakened their capacity to carry out their broader functions. Therefore } \\
\text { strengthening of their sanctioning powers was needed for full implementation of the Principle. The } \\
\text { recently approved Law on Market Abuse corrected this weakness by giving Consob and BI the } \\
\text { authority to impose pecuniary sanctions. }\end{array}$ \\
\hline Principle 4. & The regulator should adopt clear and consistent regulatory processes. \\
\hline Description & $\begin{array}{l}\text { Under the provisions of the Italian Constitution, both Consob and BI are subject to the general } \\
\text { principles fixed for public administration. These principles are contained in Law } 241 / 1990 \text {. } \\
\text { Moreover, both Consob and BI have adopted rules concerning their internal organization and the } \\
\text { procedures to be fulfilled in carrying out their activities. } \\
\text { Consob and BI consult the market and interested parties on a regular basis and before adopting } \\
\text { regulations. (Public consultations are mandatory under the new European regulatory framework.) } \\
\text { Both institutions issue guidelines responding to queries of market participants. Both regulators } \\
\text { take into account the balance of costs and benefits of the impact of proposed regulations. }\end{array}$ \\
\hline
\end{tabular}




\begin{tabular}{|c|c|}
\hline & $\begin{array}{l}\text { When Consob or BI take decisions that affect the rights of interested parties, they must provide the } \\
\text { rationale for their decisions, which can then be appealed in Court. } \\
\text { As a general principle, information in possession of Consob and BI by virtue of their supervisory } \\
\text { powers is kept confidential and covered by professional secrecy. } \\
\text { Consob plays an active role in investor education. The Consob website contains a section called the } \\
\text { "Investors' Corner," which has information for investors including "Dos and Don'ts" and warnings } \\
\text { sections. }\end{array}$ \\
\hline Assessment & Implemented \\
\hline \multicolumn{2}{|l|}{ Comments } \\
\hline Principle 5. & $\begin{array}{l}\text { The staff of the regulator should observe the highest professional standards including appropriate } \\
\text { standards of confidentiality. }\end{array}$ \\
\hline Description & $\begin{array}{l}\text { Both Consob and BI have enacted regulations concerning employees' conduct. In this regard, } \\
\text { Consob's regulations prohibit employees from performing any other activity unless expressly } \\
\text { authorized. Employees are also required to notify Consob of any fact that could generate potential } \\
\text { conflicts of interest with respect to their activities. In addition they must give notice of their } \\
\text { securities transactions, other than those involving government securities. BI has adopted similar } \\
\text { provisions. } \\
\text { Legal and regulatory requirements exist with the aim of ensuring the proper use of information } \\
\text { obtained by employees in the course of their professional activities, the confidentiality of } \\
\text { information obtained, and the prohibition on any misuse of information. When performing their } \\
\text { activities, both Consob and BI employees are regarded as public officials. }\end{array}$ \\
\hline Assessment & Implemented \\
\hline \multicolumn{2}{|l|}{ Comments } \\
\hline \multicolumn{2}{|c|}{ Principles of Self-Regulation } \\
\hline Principle 6. & $\begin{array}{l}\text { The regulatory regime should make appropriate use of Self-Regulatory Organizations (SROs) that } \\
\text { exercise some direct oversight responsibility for their respective areas of competence, and to the } \\
\text { extent appropriate to the size and complexity of the markets. }\end{array}$ \\
\hline Description & $\begin{array}{l}\text { As the Italian regulatory framework does not make use of self-regulatory authorities, this Principle } \\
\text { is inapplicable. }\end{array}$ \\
\hline Assessment & Not applicable \\
\hline Comments & No comments \\
\hline Principle 7. & $\begin{array}{l}\text { SROs should be subject to the oversight of the regulator and should observe standards of fairness } \\
\text { and confidentiality when exercising powers and delegated responsibilities. }\end{array}$ \\
\hline Description & $\begin{array}{l}\text { As the Italian regulatory framework does not make use of self-regulatory authorities, this Principle } \\
\text { is inapplicable. }\end{array}$ \\
\hline Assessment & Not applicable \\
\hline Comments & No comments \\
\hline \multicolumn{2}{|c|}{ Principles for the Enforcement of Securities Regulation } \\
\hline Principle 8. & The regulator should have comprehensive inspection, investigation and surveillance powers. \\
\hline Description & $\begin{array}{l}\text { Both Consob and BI have extensive powers to request information and conduct inspections on } \\
\text { regulated entities without prior notice. The recently approved Law on Market Abuse has also } \\
\text { provided Consob with similar powers over non regulated entities subject in most cases to prior } \\
\text { authorization from the criminal public prosecutor. } \\
\text { In the areas of their competences, both Consob and BI have been given broad supervisory powers } \\
\text { over market intermediaries. They perform on-site inspections on a regular basis. The inspection } \\
\text { procedures and operations are described in the case of Consob in the Inspection Procedure Book } \\
\text { (Manuale Ispettivo) and in the case of BI in the Guidelines to Inspections (Guida Ispettiva). Both } \\
\text { books are nonpublic documents just for internal use. } \\
\text { Joint inspections are rare. However cooperation and coordination are achieved through prior }\end{array}$ \\
\hline
\end{tabular}




\begin{tabular}{|c|c|}
\hline & $\begin{array}{l}\text { notification of inspections, so that the notified authority can ask the other for the inclusion of } \\
\text { specific issues under the scope of the inspection. } \\
\text { Regarding market supervision and surveillance, Consob is connected in real time and performs } \\
\text { daily surveillance of the regulated markets it authorizes. For this purpose it has developed an } \\
\text { electronic surveillance system (SAIVIM) which automatically detects anomalies and unusual } \\
\text { transactions. This system also allows Consob to store all the information on market transactions for } \\
\text { future investigations. BI conducts surveillance of the wholesale government securities market } \\
\text { through an intra day surveillance of liquidity indicators and periodical analysis to evaluate market } \\
\text { trends. Its system also allows it to store all the information on market transactions. Consob receives } \\
\text { all the information on the transactions carried out in the wholesale market and stores it in its own } \\
\text { database. } \\
\text { Regulated entities are obliged to keep records for the purpose of client identification which are } \\
\text { available to Consob and the judicial authorities. } \\
\text { The Italian Foreign Exchange Office, Italy's financial intelligence unit, receives suspicious- } \\
\text { transaction reports from intermediaries. Consob and BI cooperate with this office. }\end{array}$ \\
\hline Assessment & Implemented \\
\hline Comments & \\
\hline Principle 9. & The regulator should have comprehensive enforcement powers. \\
\hline Description & $\begin{array}{l}\text { The legal framework provides Consob and BI with extensive powers to enforce compliance with } \\
\text { securities laws and regulations, including precautionary measures and corrective measures, as well } \\
\text { as the imposition of administrative sanctions. In this regard, the recently approved Law on Market } \\
\text { Abuse has given Consob and BI the authority to impose pecuniary sanctions on market } \\
\text { participants. Moreover the amount of the sanctions was increased, therefore strengthening the } \\
\text { deterrence function of the disciplinary system. } \\
\text { Consob and BI must report to the public prosecutor whenever there are grounds for suspecting that } \\
\text { a criminal violation may have been committed. The decision to report to the public prosecutor has } \\
\text { to be taken by the Commission or the Governor of BI. } \\
\text { Consob can order the market operator of the regulated markets to suspend trading in any security, } \\
\text { prohibit the trading of securities on nonregulated markets, and has the power to suspend or } \\
\text { prohibit the public offering of the securities of an issuer. } \\
\text { Consob can obtain information by ad-hoc requests or through on site inspections. Consob can } \\
\text { perform on site inspections directly or it can ask the Financial Police to do so on its behalf. In such } \\
\text { cases the Financial Police reports the outcome of the inspection exclusively to Consob. The } \\
\text { information collected cannot be used by the Financial Police for any other purposes. Moreover, } \\
\text { Consob can request cooperation and assistance from other administrative bodies. Special rules } \\
\text { apply to the cooperation with the judicial authorities regarding the detection and prosecution of } \\
\text { market abuse } \\
\text { Private persons can seek remedies before a court of law for misconducts related to securities } \\
\text { matters. }\end{array}$ \\
\hline Assessment & Implemented \\
\hline Comments & $\begin{array}{l}\text { At the time of the assessment BI and Consob's enforcement powers were limited by the fact that } \\
\text { they could not imposed pecuniary sanctions as well as by the limited amount of the sanctions. Both } \\
\text { aspects needed to be addressed for full implementation of the Principle. The recently approved } \\
\text { Law on Market Abuse corrected both weaknesses. }\end{array}$ \\
\hline Principle 10. & $\begin{array}{l}\text { The regulatory system should ensure an effective and credible use of inspection, investigation, } \\
\text { surveillance and enforcement powers and implementation of an effective compliance program. }\end{array}$ \\
\hline
\end{tabular}




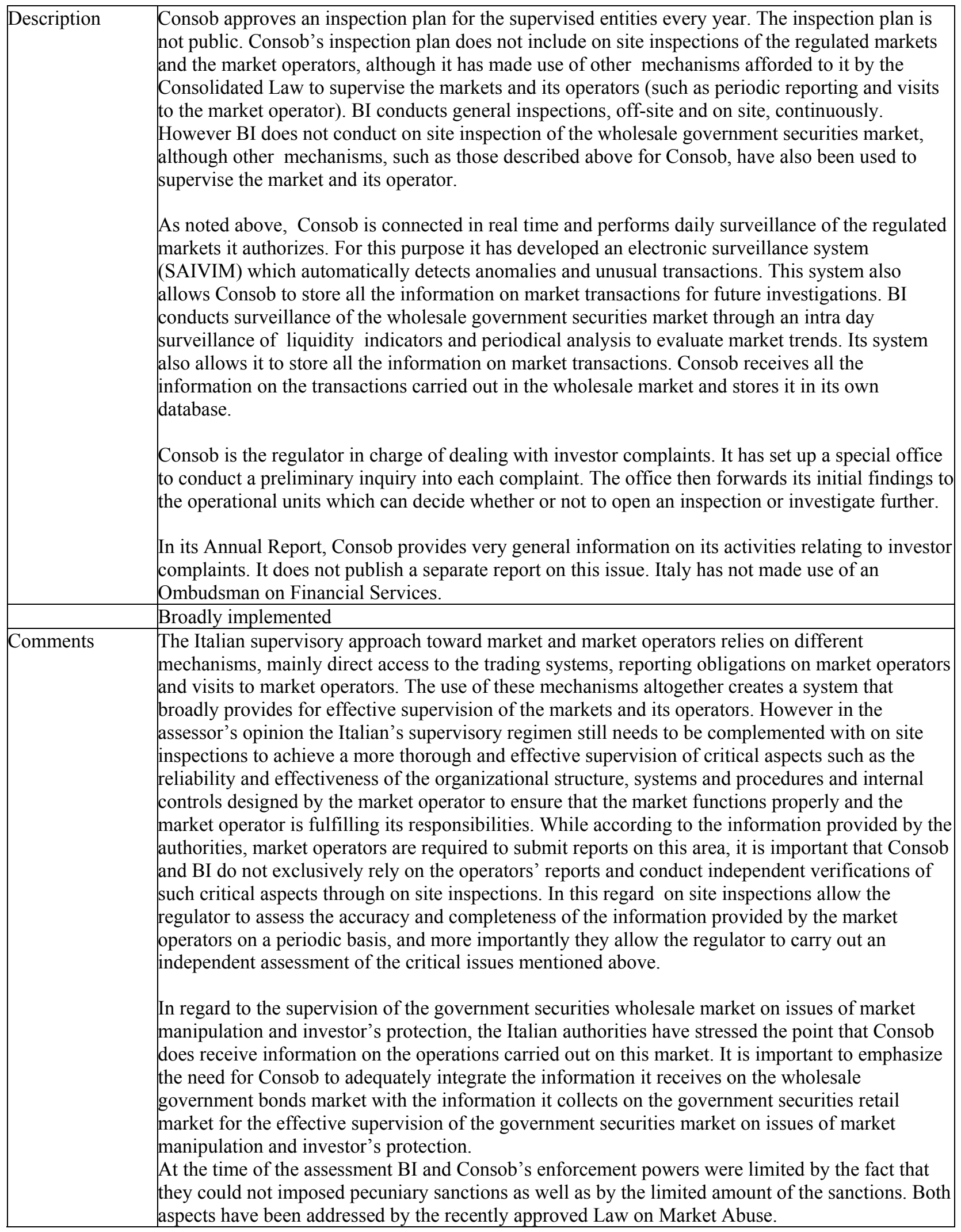




\begin{tabular}{|c|c|}
\hline & $\begin{array}{l}\text { In the view of the assessor, disclosure of investor complaints could be substantially improved by } \\
\text { establishing a separate and extensive report with detailed information on the activities performed } \\
\text { by Consob. }\end{array}$ \\
\hline \multicolumn{2}{|c|}{ Principles for Cooperation in Regulation } \\
\hline Principle 11. & $\begin{array}{l}\text { The regulator should have authority to share both public and non-public information with domestic } \\
\text { and foreign counterparts. }\end{array}$ \\
\hline Description & $\begin{array}{l}\text { The Consolidated Law requires Consob and BI to cooperate effectively. As mentioned above, } \\
\text { Consob and BI have an internal protocol covering the terms of their cooperation. Since October } \\
2005 \text { this internal protocol is public. } \\
\text { Since co-operation is mandatory under the provisions of the Consolidated Law and the } \\
\text { Consolidated Law on Banking, Consob and BI cooperate with the other Italian supervisory } \\
\text { agencies - the pension funds authority ("Covip"), the insurance supervisor ("Isvap"), and the anti- } \\
\text { money laundering authority ("UIC"). A protocol between UIC and Consob has existed since 1991. } \\
\text { This protocol is not public. There are no protocols with Isvap or Covip. } \\
\text { The domestic regulators cannot invoke professional secrecy requirements against one another. } \\
\text { No external approval is needed to exchange information with foreign counterparts. Both Consob } \\
\text { and BI are legally empowered to use their powers at the request of their foreign counterparts. } \\
\text { Moreover the recently approved Law on Market Abuse expressly grants Consob the authority to } \\
\text { carry out inspections within Italian territory on behalf of competent authorities of EU member } \\
\text { states and jurisdictions outside the EU. The staff of these authorities may accompany Consob } \\
\text { personnel in conducting on site inspections. There is also no limitation with respect to the } \\
\text { provision of unsolicited assistance. } \\
\text { The Law on Market Abuse also strengthened the confidentiality provisions related to the } \\
\text { information obtained by Consob through international cooperation. }\end{array}$ \\
\hline Assessment & Implemented \\
\hline Comments & Consideration should be given to establish protocols with the domestic supervisors. \\
\hline Principle 12. & $\begin{array}{l}\text { Regulators should establish information sharing mechanisms that set out when and how they will } \\
\text { share both public and nonpublic information with their domestic and foreign counterparts. }\end{array}$ \\
\hline Description & $\begin{array}{l}\text { Information sharing mechanisms are established to enhance cooperation between domestic } \\
\text { regulators. } \\
\text { In addition, Consob has a significant number of bilateral memoranda of understanding with its } \\
\text { foreign counterparts. Notably, Consob is a signatory of the Multilateral Memorandum of } \\
\text { Understanding of both CESR (Committee of European Securities Regulators) and IOSCO. Consob } \\
\text { also has signed the Boca Raton Declaration on the supervision of derivatives markets. } \\
\text { With regard to its activities relating to the supervision of the securities markets, BI has bilateral } \\
\text { memoranda of understanding with its principal European counterparts. BI is also a signatory to the } \\
\text { CESR MOU. Cooperation with banking supervisors in G10 countries outside Europe is based on } \\
\text { an exchange of letters. } \\
\begin{array}{l}\text { Due to the direct link between the French and the Italian Central Counterparties (CCP), Consob } \\
\text { and BI have signed an MOU with the French supervisory authorities to enhance the exchange of } \\
\text { information between the two jurisdictions in this area. }\end{array}\end{array}$ \\
\hline Assessment & Implemented \\
\hline Comments & The Principle is fully implemented and the MOUs are easily accessible on the Consob website. \\
\hline Principle 13. & $\begin{array}{l}\text { The regulatory system should allow for assistance to be provided to foreign regulators who need to } \\
\text { make inquiries in the discharge of their functions and exercise of their powers. }\end{array}$ \\
\hline
\end{tabular}




\begin{tabular}{|c|c|}
\hline Description & $\begin{array}{l}\text { As mentioned in Principle } 12 \text {, Consob is a signatory of the IOSCO Multilateral Memorandum of } \\
\text { Understanding. Prior to becoming a signatory of this MOU, IOSCO engaged in a screening process } \\
\text { to ensure that Consob could meet the MOU's standards which require that the signatories be able } \\
\text { to provide assistance to foreign authorities who need to make inquiries in the discharge of their } \\
\text { functions and the exercise of their powers. Thus, IOSCO has determined that Consob has the } \\
\text { ability to keep records sufficient to reconstruct all securities and derivatives transactions, including } \\
\text { records of all funds and assets transferred into and out of bank and brokerage accounts relating to } \\
\text { those transactions, and the ability to provide this information to its foreign counterparts on their } \\
\text { request. Consob offers timely assistance to foreign regulator with respect to, among others, insider } \\
\text { dealing, market manipulation, market intermediaries and regulated markets and clearing and } \\
\text { settlement infrastructure providers. }\end{array}$ \\
\hline Assessment & Implemented \\
\hline Comments & \\
\hline \multicolumn{2}{|c|}{ Principles for Issuers } \\
\hline Principle 14. & $\begin{array}{l}\text { There should be full, accurate and timely disclosure of financial results and other information that } \\
\text { is material to investors' decisions. }\end{array}$ \\
\hline Description & $\begin{array}{l}\text { The majority of the rules applicable to public offerings are contained in the Consolidated Law as } \\
\text { well as secondary legislation drafted by Consob. However, the current legal and regulatory } \\
\text { framework will be revised to transpose and implement the European Union Prospectus Directive } \\
\text { and the Regulation of the European Commission. } \\
\text { Persons who make public offerings in Italy (and do not fall within one of the exemptions } \\
\text { contemplated in the Law) are obliged to draw up a prospectus subject to Consob approval. The } \\
\text { information requirements for the prospectus are clearly stated in Consob regulations. Consob has } \\
\text { the authority to approve, reject, or delay an offering in order to require further information or } \\
\text { clarification from the issuer. Following Consob approval, the prospectus can be made public. } \\
\text { The requirement to publish a prospectus does not apply to offers of non listed debt instruments } \\
\text { issued by banks. Thus, banks may offer debt instruments to retail investors in Italy without being } \\
\text { subject to the prospectus review requirements of Consob. However, banks are required to provide } \\
\text { the "Foglio Informativo" which describes the main features of the instruments. Consob has noted } \\
\text { that its disclosure requirements are already substantially in line with the forthcoming EU } \\
\text { Directive. } \\
\text { Currently annual, half-yearly and quarterly reports are mandatory for companies admitted to } \\
\text { trading Borsa Italiana. } \\
\text { With respect to timely disclosure of price-sensitive information, the Consolidated Law and Consob } \\
\text { regulation require issuers (and their controlling shareholders) to inform the public of events that } \\
\text { could have a significant effect on the price of the securities. In addition, Consob can at any time } \\
\text { require issuers to publish information which it believes necessary for full disclosure. If the issuer } \\
\text { does not comply, Consob itself can publish the information at the expenses of the issuer. There are } \\
\text { also reporting obligations of substantial shareholdings, as well as insider's shareholdings as } \\
\text { described in Principle } 15 \text {. } \\
\text { Where necessary to ensure full information to orderly functioning of the market, Consob may } \\
\text { suspend the trading of financial instruments to enhance the protection of the investors. }\end{array}$ \\
\hline Assessment & Implemented \\
\hline Comments & $\begin{array}{l}\text { Information disclosure could be improved if the exemption from the prospectus requirement for } \\
\text { bank-issued debt were eliminated. This exemption was eliminated by the recently adopted Savings } \\
\text { Law. }\end{array}$ \\
\hline Principle 15. & Holders of securities in a company should be treated in a fair and equitable manner. \\
\hline Description & The Italian Civil Code contains the main provisions with regard to the treatment and rights of \\
\hline
\end{tabular}




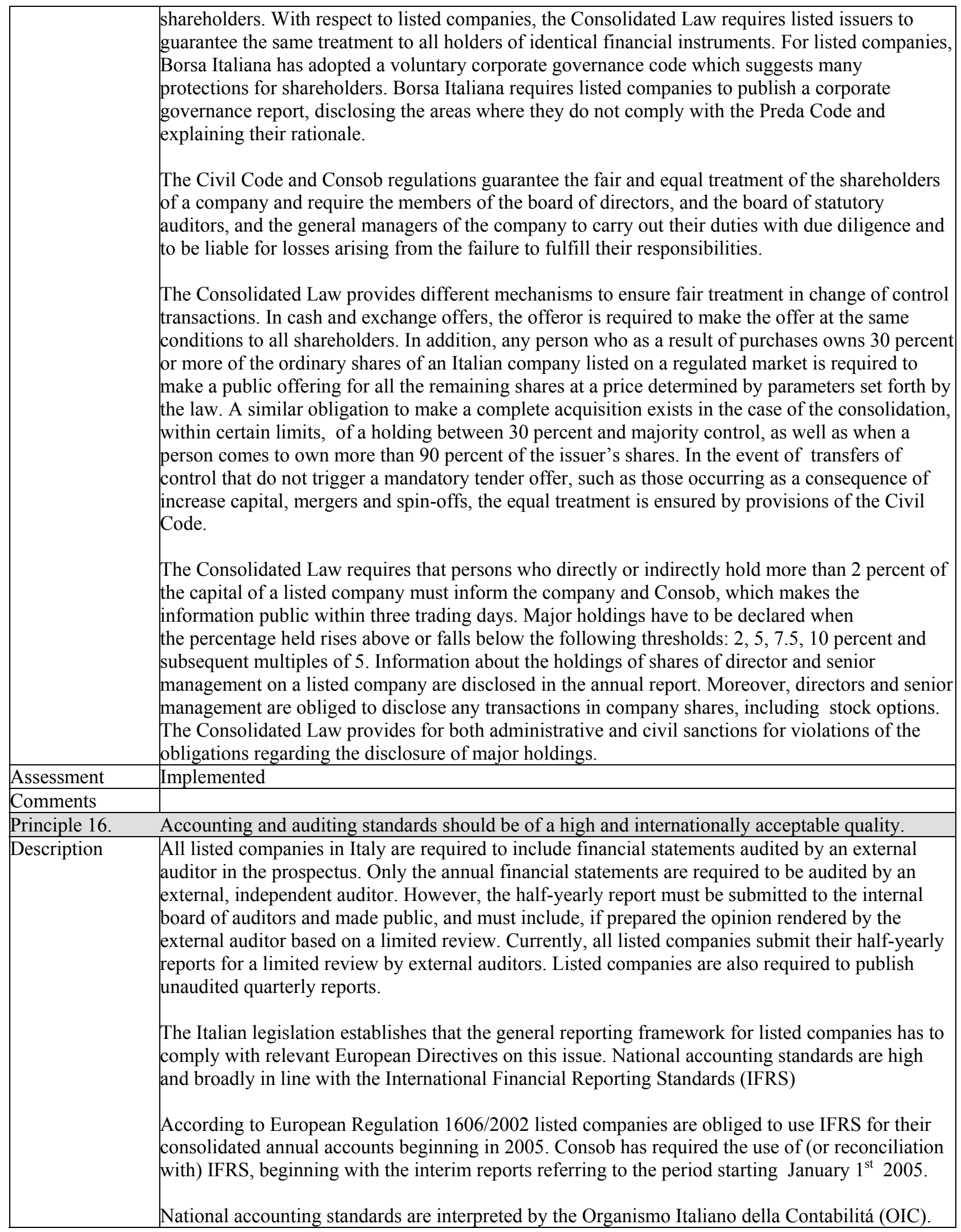




\begin{tabular}{|c|c|}
\hline & $\begin{array}{l}\text { This institution has been set up and funded by members of the private sector, including, for } \\
\text { example, Borsa Italiana. Consob and BI are observers. } \\
\text { Starting with the financial statements for the year ended on } 31 \text { December 2002, Consob } \\
\text { recommended the adoption of a new set of auditing standards that are in line with the International } \\
\text { Standards of Auditing. Moreover, national standards are generally stricter than the ISA } \\
\text { (International Standards of Auditing). } \\
\text { Rotation of auditing firm's mandatory in Italy after a period of three years; although their term of } \\
\text { engagement can be renewed for two subsequent three year terms. } \\
\text { As regards listed companies, the Consolidated Law establishes an independent body, the internal } \\
\text { board of auditors, in charge overseeing the management of the company. The board of auditors is } \\
\text { required to give an opinion to the shareholders regarding their appointment or revocation of the } \\
\text { external auditors. } \\
\text { External auditors of listed firms must be included in the Consob Special Register. According to the } \\
\text { Consolidated Law, Consob supervises the activity of the auditing firms in the Special Register to } \\
\text { verify their independence and their technical adequacy. Consob has introduced a new quality } \\
\text { assurance system to oversee the work of the auditing firms. } \\
\text { Consob has an adequate mechanism in place to enforce compliance with accounting standards. } \\
\text { Consob can request disclosure of additional information and ask issuers to restate their financial } \\
\text { statements. In case the issuer does not comply with Consob's request, Consob can sue the issuer } \\
\text { before the Civil Court. }\end{array}$ \\
\hline Assessment & Implemented \\
\hline Comments & $\begin{array}{l}\text { The auditor's oversight program could be improved if more resources were provided; however the } \\
\text { assessor acknowledges that Consob is one of the few regulators given authority to perform } \\
\text { auditor's oversight and that a system for auditors' oversight is not yet provided by European } \\
\text { Directives. }\end{array}$ \\
\hline \multicolumn{2}{|c|}{ Principles for Collective Investment Schemes } \\
\hline Principle 17. & $\begin{array}{l}\text { The regulatory system should set standards for the eligibility and the regulation of those who wish } \\
\text { to market or operate a collective investment scheme. }\end{array}$ \\
\hline Description & $\begin{array}{l}\text { The Italian regulatory framework provides specific authorization standards for both Collective } \\
\text { Investment Schemes (CIS) and CIS operators. CIS can be managed only by an authorized person } \\
\text { (the asset manager) and the assets have to be entrusted to a depository bank. } \\
\text { Consob and BI share oversight of CIS and CIS operators, in accordance with the overall functional } \\
\text { approach to supervision. However, BI is in charge of authorization of CIS, as well as financial } \\
\text { stability of CIS and CIS operators, and keeps the register of CIS. Consob is responsible for matters } \\
\text { regarding transparent and proper conduct of CIS operators and CIS public offerings. } \\
\text { The authorization to manage collective schemes is based on the fulfillment of a set of criteria that } \\
\text { includes capital adequacy, integrity and experience requirements for controlled functions, and } \\
\text { adequacy of internal controls and management systems. Asset managers are also subject to } \\
\text { periodic reporting. } \\
\text { BI and Consob conduct both on site and off site inspections. Joint on site inspections are rare; } \\
\text { however mechanisms are in place to ensure coordination among the agencies. In this regard, } \\
\text { inspections are notified to the other authority beforehand and that authority can request the } \\
\text { inclusion of issues under its consideration within the scope of the inspection } \\
\text { Inspections of CIS are included in Consob's annual inspection plan. BI's supervision is conducted }\end{array}$ \\
\hline
\end{tabular}




\begin{tabular}{|c|c|}
\hline & $\begin{array}{l}\text { mainly by monitoring of the activities of CIS through analysis of CIS reports submitted on a } \\
\text { regular basis. } \\
\text { Consob supervises the "door-to-door selling" activities of CIS by financial salespersons. However } \\
\text { as these financial salespersons are allowed to sell other financial products, either banking of } \\
\text { insurance, Isvap-the insurance regulator- can supervise these persons should they sell insurance } \\
\text { products. }\end{array}$ \\
\hline Assessment & Implemented \\
\hline \multicolumn{2}{|l|}{ Comments } \\
\hline Principle 18. & $\begin{array}{l}\text { The regulatory system should provide for rules governing the legal form and structure of collective } \\
\text { investment schemes and the segregation and protection of client assets. }\end{array}$ \\
\hline Description & $\begin{array}{l}\text { The custody of assets of CIS must be entrusted to a depositary bank. The depositary bank must act } \\
\text { independently and in the interest of the unit-holders. BI regulation establishes the conditions for } \\
\text { accepting appointment as depositary bank. These credit institutions are subject to the regular } \\
\text { supervision of BI. } \\
\text { Italian regulation provides requirements for the legal form and structure of CIS. The form and } \\
\text { structure must be disclosed, respectively, in the CIS's rules and in the CIS's prospectus, both of } \\
\text { which are subject to authorizations procedures. }\end{array}$ \\
\hline Assessment & Implemented \\
\hline \multicolumn{2}{|l|}{ Comments } \\
\hline Principle 19. & $\begin{array}{l}\text { Regulation should require disclosure, as set forth under the principles for issuers, which is } \\
\text { necessary to evaluate the suitability of a collective investment scheme for a particular investor and } \\
\text { the value of the investor's interest in the scheme. }\end{array}$ \\
\hline Description & $\begin{array}{l}\text { The offering of CIS units are subject to similar rules applicable to the public offering of financial } \\
\text { instruments. In that sense CIS operators-namely asset management companies - have to prepare } \\
\text { a comprehensive prospectus that allows investors to evaluate the proposed investment. } \\
\text { Dissemination of information both before and after the publication of the prospectus is regulated in } \\
\text { detail. It should be noted that the content of the prospectus is mainly fixed by European legislation } \\
\text { on this matter. CIS are also subject to periodic reporting. }\end{array}$ \\
\hline Assessment & Implemented \\
\hline \multicolumn{2}{|l|}{ Comments } \\
\hline Principle 20. & $\begin{array}{l}\text { Regulation should ensure that there is a proper and disclosed basis for asset valuation and the } \\
\text { pricing and the redemption of units in a collective investment scheme. }\end{array}$ \\
\hline Description & $\begin{array}{l}\text { According to the Consolidated Law, BI, after consulting Consob, establishes the criteria or } \\
\text { methods for valuing CIS assets and calculating the net asset value. } \\
\text { The valuation criteria follow national generally accepted accounting standards and are consistent } \\
\text { with IFRS. BI has specified the actions that asset management companies must take in the case of } \\
\text { pricing errors. These errors have to be communicated to the BI with an indication of the cause and } \\
\text { the way investors and the fund are to be indemnified. The CIS's external auditing firm is required } \\
\text { to verify compliance with the valuation rules. They also are required to render an opinion to be } \\
\text { included in the fund report. }\end{array}$ \\
\hline Assessment & Implemented \\
\hline Comments & \\
\hline \multicolumn{2}{|c|}{ Principles for Market Intermediaries } \\
\hline Principle 21. & Regulation should provide for minimum entry standards for market intermediaries. \\
\hline Description & $\begin{array}{l}\text { The Consolidated Law provides the general rules concerning the authorization and licensing of } \\
\text { market intermediaries. Consob and BI regulation establish more detailed requirements for, } \\
\text { respectively, investment firms and banking institutions providing investment services. The current } \\
\text { Italian legislation on this issue is basically tailored to follow European Directives, including in } \\
\text { particular, the Investment Services Directive and the Banking Directive. In light of the extensive } \\
\text { revisions to the European regulatory framework, significant changes in the financial services }\end{array}$ \\
\hline
\end{tabular}




\begin{tabular}{|c|c|}
\hline & $\begin{array}{l}\text { environment in Italy are expected in the near future. } \\
\text { According to the Consolidated Law, Consob and BI authorize investment firms and banking } \\
\text { institutions providing investment services, respectively. After receiving an application, Consob } \\
\text { must ascertain that the conditions specified in the Consolidated Law for granting the authorization } \\
\text { are fulfilled. BI informs Consob of every authorization granted to the banks. Consob and BI verify, } \\
\text { within the scope of their competences, the program of activities of the applicants, in which they } \\
\text { describe their business plan and strategy as well as their internal procedures. Technical and } \\
\text { organizational structure and capital requirements are screened by the authorities. Consob and BI } \\
\text { can revoke a license when they consider that the investment firm or bank does not meet the } \\
\text { minimum requirements. } \\
\text { A specific license is required for financial salespersons who perform “door-to-door" selling of } \\
\text { financial services on a professional service. } \\
\text { Market intermediaries have to provide Consob with reports, data and documents on both a regular } \\
\text { and an ad hoc basis. These requirements are clearly stated in Consob regulations and, among other } \\
\text { things, include annual accounts, complaints received, modification of bylaws, and the identities of } \\
\text { the members of the board, senior staff and relevant shareholders. } \\
\text { The bulk of information provided by market participants is used to perform off-site supervision by } \\
\text { Consob and BI. Regular meetings with corporate officers of the investment firms are held to } \\
\text { provide further information or clarification. } \\
\text { With respect to on site inspections, the methods, and procedures are set out in the Guide for } \\
\text { Intermediaries Inspection adopted by BI and the Manual for the Inspections adopted by Consob. } \\
\text { Both Consob and BI perform on site inspections on a regular basis and are included in Consob's } \\
\text { Annual Inspection Plan. In general, on site inspections consist of a review based on the analysis } \\
\text { resulting from the off site supervision. The main aim is to check the conformity of supervisory } \\
\text { data to create an independent evaluation of the condition of the intermediary. As already } \\
\text { mentioned, joint inspections by Consob and BI are rare; however there are mechanisms in place to } \\
\text { ensure coordination and cooperation. }\end{array}$ \\
\hline Assessment & Implemented \\
\hline Comments & \\
\hline Principle 22. & $\begin{array}{l}\text { There should be initial and ongoing capital and other prudential requirements for market } \\
\text { intermediaries that reflect the risks that the intermediaries undertake. }\end{array}$ \\
\hline Description & $\begin{array}{l}\text { Capital requirements are required for investment firms to be authorized. The minimum initial paid- } \\
\text { up capital is established by the BI, having consulted Consob. Current requirements are more } \\
\text { stringent than those required by European legislation (Capital Adequacy Directive). In addition, } \\
\text { intermediaries are required to comply with supervisory capital requirements, whose amount } \\
\text { depends on the nature and the level of the risk incurred. This ongoing capital cannot be lower than } \\
\text { the initial capital. } \\
\text { Capital requirements are implemented to address, among others, the following risks: credit risk, } \\
\text { settlement risk, counterparty risk, concentration risk and other risks (reputational, operational, } \\
\text { legal, etc.). Investment firms may adopt internal models to calculate the capital requirements for } \\
\text { market risk subject to the approval of BI. The investment firms are required to submit sufficient } \\
\text { data to Consob and BI to verify their compliance with the requirements. } \\
\text { The two existing European Union Directives on Capital Adequacy and Banking are currently } \\
\text { causing changes in the regulatory framework of the European Union. The objective of these } \\
\text { revisions is to transpose the revised Basel Accord (Basel II) into European legislation. Significant } \\
\text { changes are expected to be made that will focus more on the supervisory approach than only on the }\end{array}$ \\
\hline
\end{tabular}




\begin{tabular}{|c|c|}
\hline & $\begin{array}{l}\text { amount of regulatory capital required. } \\
\text { Investment firms are obliged to submit to Consob their financial statements audited by external } \\
\text { auditors entered in a special register kept by Consob. In addition, external auditors must verify that } \\
\text { the records of the investment firms are properly kept, the transactions are correctly entered, and the } \\
\text { annual accounts and consolidated accounts conform with their accounting records. } \\
\begin{array}{l}\text { Auditing companies submit opinions on investment firms' annual and consolidated accounts in } \\
\text { special reports. They are also required to review the internal control system of the investment } \\
\text { firms. }\end{array}\end{array}$ \\
\hline Assessment & Implemented \\
\hline \multicolumn{2}{|l|}{ Comments } \\
\hline Principle 23. & $\begin{array}{l}\text { Market intermediaries should be required to comply with standards for internal organization and } \\
\text { operational conduct that aim to protect the interests of clients, ensure proper management of risk, } \\
\text { and under which management of the intermediary accepts primary responsibility for these matters. }\end{array}$ \\
\hline Description & $\begin{array}{l}\text { Market intermediaries are obliged to act diligently, correctly and transparently in the interest of } \\
\text { their customers and the integrity of the market. In order to mitigate conflicts of interest, market } \\
\text { intermediaries are required to implement adequate measures to prevent inappropriate information } \\
\text { exchange between different departments of the firm that need to be separated (Chinese walls). } \\
\text { External auditors are required to audit the internal control systems of investment firms. External } \\
\text { auditors are obliged to communicate any anomaly to the management of the company, the internal } \\
\text { board of auditors and the regulator. } \\
\text { Under Consob regulation, market intermediaries are required to have specific procedures to deal } \\
\text { with customer complaints. In addition, customers are entitled to take legal action for damages } \\
\text { relating to the provision of financial services. } \\
\text { Specific provisions issued by BI, after consulting with Consob, have been adopted to safeguard the } \\
\text { assets of the clients. Unless customers have agreed otherwise in writing, investment firms and } \\
\text { banks cannot use, on their own behalf or on behalf of third parties, financial instruments belonging } \\
\text { to their customers. } \\
\text { Suitability tests are mandatory for all contracts, including those for execution-only. Thus, the } \\
\text { obligation of market intermediaries to know their customers is mandatory. In the event of refusal } \\
\text { by the customer to provide the necessary information, the intermediary is not released from its } \\
\text { obligation to evaluate the suitability of the services provided. In addition, intermediaries must } \\
\text { adequately inform their retail customers about the products and services provided or offered. In } \\
\text { particular, intermediaries must provide potential clients with a document on the general risks } \\
\text { related to investments in financial instruments. Before specific transactions are undertaken, a copy } \\
\text { of the prospectus or other information where prescribed must be provided. Intermediaries are } \\
\text { prohibited from recommending or carrying out transactions or supplying services until they have } \\
\text { provided investors with information on the nature, risks and implications of the transaction or } \\
\text { service in question. }\end{array}$ \\
\hline Assessment & Implemented \\
\hline Comments & $\begin{array}{l}\text { In recently publicized cases Consob has taken a strong position proposing sanctions to board } \\
\text { members and audit committee member of major financial intermediaries. However, in the light of } \\
\text { recent reports of marketing by intermediaries of products without disclosure of full information of } \\
\text { the risks involved, Consob may consider whether it could enhance its monitoring of the practices } \\
\text { of intermediaries in this area and, in particular, their compliance with suitability and information } \\
\text { disclosure requirements, within the limits provided by the Prospectus Directive. }\end{array}$ \\
\hline Principle 24. & $\begin{array}{l}\text { There should be a procedure for dealing with the failure of a market intermediary in order to } \\
\text { minimize damage and loss to investors and to contain systemic risk. }\end{array}$ \\
\hline
\end{tabular}




\begin{tabular}{|c|c|}
\hline on & $\begin{array}{l}\text { The Consolidated Law and the Consolidated Law on Banking state that the competent authorities } \\
\text { may suspend the management of a market intermediary as a matter of urgency and appoint a } \\
\text { provisional administrator to take over their management. With regard to the investment firms, it is } \\
\text { the Chairperson of Consob who appoints this administrator. } \\
\text { In the event of insolvency, the Ministry of Economic and Finance, upon proposal of Consob or BI, } \\
\text { may issue a decree withdrawing authorization to carry on business and ordering the compulsory } \\
\text { liquidation of the firm. BI is responsible for overseeing the procedure as well as all related } \\
\text { formalities. } \\
\text { Consob and BI have extensive powers to convene the directors, members of the board of auditors } \\
\text { and manager. BI may authorize the transfer of assets and liabilities to other firms. } \\
\text { BI and Consob provide comprehensive information disclosing emergency procedures in place for } \\
\text { market intermediaries every month and every fifteen days respectively. } \\
\text { Before obtaining authorization, investment firms are obliged to apply for membership in an } \\
\text { investor compensation scheme recognized by the Minister of Economy and Finance, after } \\
\text { consulting Consob and BI. The regulation and operation of the investor compensations schemes are } \\
\text { in line with relevant European legislation, i.e. Investor Compensation Scheme Directive. }\end{array}$ \\
\hline Asses & Implemented \\
\hline Comn & \\
\hline \multicolumn{2}{|r|}{ Secondary Market } \\
\hline Principle 25. & $\begin{array}{l}\text { The establishment of trading systems including securities exchanges should be subject to } \\
\text { regulatory authorization and oversight. }\end{array}$ \\
\hline Desc & $\begin{array}{l}\text { The Consolidated Law establishes all the provisions concerning the authorization of exchanges and } \\
\text { trading systems and the recognition of foreign markets. More detailed regulation has been issued } \\
\text { by Consob which is the competent authority for authorizing and regulating markets and trading } \\
\text { system. } \\
\text { As a general rule, Consob is the authority that authorizes, regulates and supervises regulated } \\
\text { markets and other trading systems, except for the wholesale government securities market which is } \\
\text { authorized and regulated by the Ministry of Economy and Finance and supervised by BI. Consob } \\
\text { has authority to monitor the market for market abuse and investor protection. } \\
\text { Consob regulation establishes the minimum capital of the market operator (currently euro } \\
5 \text { million) while the MEF establishes the integrity and experience requirements for the persons } \\
\text { administering the markets as well as the integrity of the shareholders of the markets. It has to be } \\
\text { mentioned that the new European regulatory framework will impose significant changes in the } \\
\text { structure of the regulated markets and trading systems in terms of capital requirements. } \\
\text { Regulated markets or trading systems are required to satisfy Consob that the regulatory standards } \\
\text { are met on an ongoing basis. Consob checks compliance with Consob regulation and, if necessary, } \\
\text { can require the market operator to amend market rules. With respect to the wholesale government } \\
\text { securities market, BI and Consob check that market rules comply with regulation enacted by the } \\
\text { MEF. The MEF, upon proposal of BI, after consulting Consob, may require the market operator to } \\
\text { amend market rules. } \\
\text { The initial authorization of markets is granted upon positive assessment of technological resources } \\
\text { and human skills. } \\
\text { Specific regulation on trading halts is in place in both the spot and the derivatives markets. This } \\
\text { regulation has been recently updated. }\end{array}$ \\
\hline
\end{tabular}




\begin{tabular}{|c|c|}
\hline & $\begin{array}{l}\text { The conditions and procedures for admission, exclusion and suspension of market participants to } \\
\text { and from trading are established in the markets rules adopted by the market operator and approved } \\
\text { by Consob. The approval process entails assessment of the fairness and objectiveness of the access } \\
\text { criteria. The admission of intermediaries to trading is therefore subject to an examination of the } \\
\text { market operator on the basis of objective, nondiscriminatory criteria approved by Consob. There } \\
\text { are no restrictions preventing remote members from accessing the regulated markets. Remote } \\
\text { members are subject to the same rules as domestic members. } \\
\text { The market rules, including execution rules, are publicly disclosed. }\end{array}$ \\
\hline Assessment & Implemented \\
\hline \multicolumn{2}{|l|}{ Comments } \\
\hline Principle 26. & $\begin{array}{l}\text { There should be ongoing regulatory supervision of exchanges and trading systems, which should } \\
\text { aim to ensure that the integrity of trading is maintained through fair and equitable rules that strike } \\
\text { an appropriate balance between the demands of different market participants. }\end{array}$ \\
\hline Description & $\begin{array}{l}\text { As already mentioned, Consob is connected in real-time and performs daily surveillance of the } \\
\text { regulated markets it authorizes. The government bonds wholesale market is monitored in real time } \\
\text { by the BI. } \\
\text { In addition, Consob supervises the conduct of market intermediaries through the examination of } \\
\text { their business operations and regulates the disclosure of price sensitive information by issuers. } \\
\text { Similar functions are performed by BI within the scope of its competences - except that BI does not } \\
\text { perform any function with respect to regulation of price sensitive information. } \\
\text { Under the Consolidated Law, the rules of the regulated markets adopted by market operator and } \\
\text { any amendments to them are subject to the approval of Consob before entering into force. With } \\
\text { respect to the wholesale market in government securities the rules of the market operator and } \\
\text { subsequent amendments are subject to the approval of the MEF, after consulting BI and Consob. } \\
\text { As regard to the mechanisms in place to verify compliance by the exchanges or trading systems } \\
\text { with their responsibilities, no formal on site inspections are performed on regulated markets by } \\
\text { Consob or BI. Moreover on site supervision of regulated markets is not included in the Consob } \\
\text { Annual Inspection Plan, although frequent informal contacts by telephone and visits by the staff of } \\
\text { the regulator do take place. } \\
\text { According to the Consolidated Law, in the event of serious events, the MEF, acting on a proposal } \\
\text { of Consob, may dissolve the control bodies of the market operator or, under extreme } \\
\text { circumstances, revoke the initial authorization. }\end{array}$ \\
\hline Assessment & Broadly implemented \\
\hline Comments & $\begin{array}{l}\text { The Italian supervisory approach toward market and market operators relies on different } \\
\text { mechanisms, mainly direct access to the trading systems, reporting obligations on market operators } \\
\text { and visits to market operators. The use of these mechanisms altogether creates a system that } \\
\text { broadly provides for effective supervision of the markets and its operators. However in the } \\
\text { assessor's opinion the Italian's supervisory regimen still needs to be complemented with on site } \\
\text { inspections to achieve a more thorough and effective supervision of critical aspects such as the } \\
\text { reliability and effectiveness of the organizational structure, systems and procedures and internal } \\
\text { controls designed by the market operator to ensure that the market functions properly and the } \\
\text { market operator is fulfilling its responsibilities. While according to the information provided by the } \\
\text { authorities, market operators are required to submit reports on this area, it is important that Consob } \\
\text { and BI do not exclusively rely on the operators' reports and conduct independent verifications of } \\
\text { such critical aspects through on site inspections. In this regard on site inspections allow the } \\
\text { regulator to assess the accuracy and completeness of the information provided by the market } \\
\text { operators on a periodic basis, and more importantly they allow the regulator to carry out an }\end{array}$ \\
\hline
\end{tabular}




\begin{tabular}{|c|c|}
\hline & $\begin{array}{l}\text { independent assessment of the critical aspects mentioned above. } \\
\text { In regard to the supervision of the government bonds wholesale market on issues of market } \\
\text { manipulation and investor's protection, the Italian authorities have stressed the point that Consob } \\
\text { does receive information on the operations carried out on this market. It is important to emphasize } \\
\text { the need for Consob to adequately integrate the information it receives on the wholesale } \\
\text { government bonds market with the information it collects on the government securities retail } \\
\text { market for the effective supervision of the government securities market on issues of market } \\
\text { manipulation and investor's protection. }\end{array}$ \\
\hline Principle 27. & Regulation should promote transparency of trading. \\
\hline Description & $\begin{array}{l}\text { Under the provisions of the Consolidated Law, market operators have to establish comprehensive } \\
\text { procedures for the verification, publication and dissemination of prices to market participants and } \\
\text { the public. } \\
\text { The market rules promoting the transparency of trading have to be approved by Consob and have } \\
\text { to be consistent with Consob regulations. Market operators are obliged to disseminate information } \\
\text { relating to the contracts concluded for each financial instrument, i.e. price and volume. This } \\
\text { information is disclosed to the public via the electronic trading support systems or, if necessary, via } \\
\text { third parties. } \\
\text { At the end of each trading day, markets are also required to publish an "Official List" containing } \\
\text { information on the contracts concluded for each financial instrument. Information is made } \\
\text { available via electronic data processing and telecommunication systems and it is easily accessible } \\
\text { through the website of the regulated markets, i.e. Borsa Italiana. } \\
\text { With respect to pre-trade transparency requirements, as an order-driven market, Borsa Italiana, } \\
\text { provides extensive information, posting the bids and offers of each stock admitted to trading. } \\
\text { Standards of transparency are also high in the quote-driven market, i.e. the wholesale government } \\
\text { securities markets and alternative trading systems. } \\
\text { It has to be said that upcoming European regulation will have a significant impact in the current } \\
\text { environment of the Italian securities markets. In this regard, the elimination of the concentration } \\
\text { rule, the multiplication of trading venues and the possibility for financial institutions to internalize } \\
\text { client orders will have a significant impact in the transparency of the markets that will have to be } \\
\text { taken into account by the regulators. }\end{array}$ \\
\hline Assessment & Implemented \\
\hline Comments & \\
\hline Principle 28. & Regulation should be designed to detect and deter manipulation and other unfair trading practices. \\
\hline Description & $\begin{array}{l}\text { The recently approved Law on Market Abuse has strengthened the disciplinary framework } \\
\text { concerning market manipulation and insider trading. } \\
\text { A wide range of penal sanctions is envisaged for insider traders, who can now be punished by up to } \\
\text { six years in prison and a fine of } 3 \text { million euro. Market manipulation is punishable by up to six } \\
\text { years in prison and a } 5 \text { million euro fine. } \\
\text { The Law also includes administrative sanctions to be applied by Consob for both types of } \\
\text { conducts. } \\
\text { Consob monitors the markets in real time to detect unusual or suspicious transactions carried out in } \\
\text { the markets. }\end{array}$ \\
\hline
\end{tabular}




\begin{tabular}{|c|c|}
\hline & $\begin{array}{l}\text { Continuous monitoring of trading is made by, among other things, the examination of the } \\
\text { transactions made by market intermediaries and the obligation of issuers to disclose any significant } \\
\text { event or price sensitive information. Consob does not monitor the wholesale government securities } \\
\text { market on a real time basis. }\end{array}$ \\
\hline Assessment & Implemented \\
\hline Comments & $\begin{array}{l}\text { In regard to the supervision of the government bonds wholesale market on issues of market } \\
\text { manipulation and investor's protection, the Italian authorities have stressed the point that Consob } \\
\text { does receive information on the operations carried out on this market. It is important to emphasize } \\
\text { the need for Consob to adequately integrate the information it receives on the wholesale } \\
\text { government bonds market with the information it collects on the government securities retail } \\
\text { market for the effective supervision of the government securities market on issues of market } \\
\text { manipulation and investor's protection. }\end{array}$ \\
\hline Principle 29. & $\begin{array}{l}\text { Regulation should aim to ensure the proper management of large exposures, default risk and } \\
\text { market disruption. }\end{array}$ \\
\hline Description & $\begin{array}{l}\text { Large exposures are monitored, on a real time basis, by authorised intermediaries, clearing houses } \\
\text { and market operators, under the ultimate responsibility of BI and Consob. Supervisory activity } \\
\text { aims at preventing counterparty risk, systemic risk and manipulative practices risk. } \\
\text { BI monitors the large exposures of the clearing house's participants on the proprietary and } \\
\text { customers' accounts through its connection to the internal system of the Cassa di Compensazione e } \\
\text { Garanzia (C\&G), the Italian clearing house. Consob receives from CC\&G, at the end of the trading } \\
\text { day, reports on long and short open positions held by each market participant in both the } \\
\text { proprietary and customers' accounts. Both Consob and BI may ask market participants for } \\
\text { information and records concerning activities carried out on their own account and on behalf of } \\
\text { their customers along with any other relevant information including the beneficial ownership of the } \\
\text { positions held by direct customers. } \\
\text { Failure to comply with any request for information by BI and Consob is punishable by } \\
\text { administrative sanctions. Providing false information to BI or Consob and obstructing the conduct } \\
\text { of their functions is a criminal offence. } \\
\text { In the most serious cases, the BI and Consob, within the scope of their respective competence, may } \\
\text { propose to the MEF to revoke the authorisation. } \\
\text { Consob, in agreement with BI, establishes the regulation with respect to the insolvency of market } \\
\text { participants of the clearing house. Consob is in charge of declaring the insolvency of a market } \\
\text { participant and regulates the procedures for liquidation of, among other things, transactions } \\
\text { concluded off the regulated markets, block trades, settlements, forward contracts and traditional } \\
\text { options contracts concluded off the regulated markets, and transactions involving financial } \\
\text { instruments not listed on an Italian regulated market. } \\
\text { Consob the B.I. cooperate and exchange information with domestic and foreign regulators through } \\
\text { the signatory of different MOUs. Within the European Union the Settlement Finality Directive } \\
\text { establishes the procedures to communicate an insolvency of a clearing house participant. BI is the } \\
\text { competent authority for the official communication. }\end{array}$ \\
\hline Assessment & Implemented \\
\hline \multicolumn{2}{|l|}{ Comments } \\
\hline Principle 30. & $\begin{array}{l}\text { Systems for clearing and settlement of securities transactions should be subject to regulatory } \\
\text { oversight, and designed to ensure that they are fair, effective and efficient and that they reduce } \\
\text { systemic risk. }\end{array}$ \\
\hline Description & See IOSCO-CPSS Assessment. \\
\hline Assessment & See IOSCO-CPSS Assessment. \\
\hline Comments & See IOSCO-CPSS Assessment. \\
\hline
\end{tabular}


Table 2. Summary Implementation of the IOSCO Objectives and Principles of Securities Regulation

\begin{tabular}{|l|l|l|}
\hline $\begin{array}{l}\text { Assessment } \\
\text { Grade }\end{array}$ & \multicolumn{2}{l|}{ Principles Grouped by Assessment Grade } \\
\hline & Count & List \\
\hline Implemented & 25 & $\begin{array}{l}\text { P 1, 2, 3, 4, 5 8, 9, 11, 12, 13, 14, 15, 16, 17, 18, 19, 20, 21, 22, 23, 24, 25, 27, } \\
28,29\end{array}$ \\
\hline $\begin{array}{l}\text { Broadly } \\
\text { Implemented }\end{array}$ & 2 & P 10,26 \\
\hline Partly Implemented & & \\
\hline Not Implemented & & \\
\hline Not applicable & 2 & P 6,7 \\
\hline
\end{tabular}

Table 3. Recommended Plan of actions to improve implementation of the IOSCO Objectives and Principles of Securities Regulation

\begin{tabular}{|l|l|}
\hline Reference Principle & Recommended action \\
\hline Principles for the regulator & $\begin{array}{l}\text { Recommendations regarding legal protection } \\
\text { of BI staff are included in the BCP } \\
\text { Assessment. }\end{array}$ \\
\hline Principles for the enforcement of securities & $\begin{array}{l}\text { 1. On site inspections of market operators } \\
\text { and regulated markets should be included in } \\
\text { Consob's and BI's inspection plans. } \\
\text { 2. Transparency regarding investor's } \\
\text { complaints would be enhanced with a } \\
\text { separate an extensive report on activities } \\
\text { performed by Consob. }\end{array}$ \\
\hline Principles for issuers & $\begin{array}{l}\text { Full prospectus requirements as provided in } \\
\text { the Prospectus Directive (2003/71EC) should } \\
\text { be applied to non listed debt instruments } \\
\text { issued by banks. }\end{array}$ \\
\hline Principles for market intermediaries & $\begin{array}{l}\text { Consob should consider enhance monitoring } \\
\text { of market intermediaries to ensure } \\
\text { compliance with suitability and information } \\
\text { disclosure requirements, within the limits of } \\
\text { the MIFID Directive. }\end{array}$ \\
\hline Principles for secondary markets & $\begin{array}{l}\text { On site inspections of both market operators } \\
\text { and regulated markets should be conducted } \\
\text { by Consob and BI. }\end{array}$ \\
\hline
\end{tabular}

${ }^{8}$ This was addressed by the recently adopted Savings Law. 


\section{Authorities' response to the assessment}

The Bank of Italy and CONSOB contend that Principles 10 and 26 have been fully implemented.

They consider that, so far, planning routine on site inspections on the market operator on an annual basis has not been necessary to ensure effective supervision of markets and market operators. Both Consob -for all markets - and BI -for the wholesale government bonds market- have direct access to the information on the trading systems, which is complemented by the periodic information that market operators have to send to them, and that includes annual accounts, as well as an annual report on internal control issues.

In the view of Consob and BI IOSCO Principle 8, as specified by the Methodology Key question 3), requires that the regulator is able to perform "surveillance" on the markets (which is defined under Principle 25) and leaves it to the regulator to decide which mix of supervisory tools should be used. IOSCO Principles (see Principle 26) do not require that on-site inspections of market operators be included in an annual plan of supervision (it is sufficient to have the power to perform inspections if necessary). The Principles require that mechanisms are in place (key question 1) which allow for a surveillance program of the trading or of the trading system and of the behavior of the intermediaries. Principle 28 (key Question 2) requires that the system provides (among the different methods listed) a combination which ensures the correct monitoring and detection of possible market abuse.

By directly supervising the trading on the market and the behavior of the market members (including through checks on their trading strategies and their positions) Consob and BI - for the wholesale government bonds markets - can identify any anomalies or inability of the market operator to maintain orderly trading on the platform. It should also be recalled that pursuant to Article 74 paragraph 3, in cases of necessity and as a matter of urgency Consob can adopt all necessary measures acting in the place of the market management company; the same powers are attributed to the BI with regard to the wholesale government bonds market (Article 76, paragraph 1).

In addition, Consob and BI make regular use of other mechanisms for continuous monitoring, such as regular visits to market operators (twice per month) and contacts with the staff of market operators to keep informed of market's developments; the company has also been providing the authorities with periodic reports required by the Supervisory Instructions on organizational risk management and technological infrastructure made by external auditors. Furthermore the authorities receive in advance the agenda of the board's meetings and have the power to ask that items be included in it. Also, Consob has to approve the rules of the market.

However, it should be noticed that following the privatization of the market operators in 1996, Consob has performed to date 2 on site inspections pursuant to Article 74 paragraph 2 of the Consolidated Law on the Italian Stock Exchange. 
Banca d'Italia has statutory powers to conduct on-site inspections on the operators of wholesale markets on government bonds. Inspections will be carried out, as necessary, based on a methodology that has been recently adopted and is applicable also to other market infrastructures. This methodology aims at integrating the information received with an appraisal of the reliability and effectiveness of organizational structure, systems and procedures and internal controls.

Finally, the authorities consider that the system in place for the supervision of the wholesale government securities market is effective also on the issues of market manipulation and investor's protection. Consob receives all the data on the transactions performed in this market and stores it in its data base so that it can be analyzed to identify possible market abuse. In addition, Consob conducts real time monitoring of the retail market for government securities, which constitutes an additional input fur the purposes of detecting problems in price formation in the government bonds market. 